\title{
Cuban Scientific Production on Diabetes, 2000-2017: Peer-reviewed Publications, Collaboration and Impact
}

\author{
Ibraín E. Corrales-Reyes DDS, Yasmany Fornaris-Cedeño, Alberto J. Dorta-Contreras MS PhD, \\ Christian R. Mejia MD MS PhD, Josmel Pacheco-Mendoza DVM MS, Ricardo Arencibia-Jorge PhD
}

\begin{abstract}
INTRODUCTION The steadily increasing prevalence of diabetes globally has captured researchers' attention. Cuban production of scientific articles on diabetes has not been studied from a bibliometric perspective.
\end{abstract}

OBJECTIVE Characterize the production and impact of research and review articles on diabetes by Cuban authors in journals listed in the Scopus bibliographic database, as well as related collaboration among Cuban institutions and between Cuban and non-Cuban institutions

METHODS A bibliometric analysis was conducted using 2000-2017 data from the Scopus database. The following search strategy was used: descriptor (diabetes), country (Cuba), publication source (journal), article type (original research, review article). Bibliographic indicators of production, visibility, impact and collaboration were examined.

RESULTS Cuba contributed $3.2 \%$ of Latin American production and $0.1 \%$ of global production related to diabetes. Within Cuba's scientific production (610 articles, 538 original research and 72 review), 85.9\% had a Cuban corresponding author (Cuban leadership). In articles

\section{INTRODUCTION}

The term diabetes includes type 1 and type 2 diabetes mellitus (DM) (the most common), maturity onset diabetes of the young (of which seven types have been described), diabetes related to cystic fibrosis, medication-induced diabetes and gestational diabetes.[1] Due to its high mortality and morbidity, DM is a global public health problem of unquestionable importance. [2-4] It is characterized by insulin deficiency or resistance, or a combination of both. $[5,6]$ Type 1 DM is a chronic autoimmune disease that primarily affects children and adolescents.[6,7] Type 2 DM is characterized by high blood sugar that can develop asymptomatically.[6] In general, independent of its classification, DM can cause chronic vascular damage, which produces many severe complications.[8]

According to the International Diabetes Federation, 451 million people worldwide aged 18-99 years suffered from diabetes in 2017 (and in some countries, as many as 1 in 2 diabetics is likely to be undiagnosed), the number expected to increase to 693 million by 2045.[9] The average prevalence of DM in South and Central America is $8 \%$, with wide variations among and within

IMPORTANCE This article is a wakeup call that one of the most important chronic conditions in Cuba, and Cuban strategies for addressing it, are not sufficiently reflected in the international literature. with international collaboration (22.9\%), however, most (67.9\%) had non-Cuban corresponding authors. A total of $47 \%$ (287) were articles involving a single institution. Only $11.1 \%$ were published in top-ranked journals, and $14.4 \%$ were cited $>10$ times. Cubans were lead authors on $0.3 \%$ of the most frequently cited (top 10\%) articles on diabetes in Scopus. A total of $38.4 \%$ of this production appeared in low-impact journals and $57.9 \%$ in Cuban journals.

Articles published in English accounted for 30\% of total and obtained higher impact in terms of citations than articles in Spanish. The strongest networks for scientific collaboration were those that connected Cuban and US researchers.

CONCLUSIONS Cuban scientists conduct research on diabetes, but their work is not highly visible in the peer-reviewed literature, particularly in top-ranked journals. The problem is not simply one of publishing more, but of knowing how and where to publish. It is urgent that Cuban universities training health professionals at all levels include instruction on scientific writing.

KEYWORDS Diabetes, health services research, scientific journals, bibliometrics, Cuba

countries.[10-15] In Cuba, prevalence was $6.2 \%$ of the total population (5.1\% among men and 7.2\% among women) in 2017. That same year, 2425 people died as a direct consequence of DM.[15]

Increases in diabetes morbidity, mortality and costs to individuals and health systems[10] demonstrate the need for research on this topic. Bibliometric analysis of publications on diabetes is useful in assessing the current state of research and contributions of researchers and countries, and can be a resource for those who lead research within a working group, an institution or a country.[16]

Bibliometric analysis of diabetes-specific scientific production has been carried out at the global level,[16-21] as well as for the Middle East, Iran, Nigeria, Argentina, Thailand, India, China, Brazil and Peru.[22-31] However, our literature review found no bibliometric studies of Cuban scientific production on diabetes.

This study aims to characterize production of original research and review articles on diabetes published by Cuban authors in journals included in the Scopus bibliographic database, and related collaboration among Cuban institutions and between Cuban and non-Cuban institutions.

\section{METHODS}

Design A bibliometric analysis was conducted using 2000-2017 data from the Scopus database. 
Bibliometric indicators The following indicators were studied:

- number of articles with at least one author affiliated with a Cuban institution

- total number of citations received by articles

- total number of articles cited at least once

- mean number of citations for all articles retrieved

- percentage of articles involving collaboration

- type of collaboration-

- none (article entirely produced within a single Cuban institution, regardless of number of authors or departments involved)

- national (author affiliations include more than one Cuban institution)

- international (author affiliations include institutions in at least one other country besides Cuba)

- national and international (author affiliations include institutions from more than one Cuban institution and at least one other country)

- h-index. This considers both number of articles and number of citations. An author's h-index equals $x$ if they have $x$ articles cited at least $x$ times.[32] May be applied to groups of authors, departments or countries, as well as individuals.

- growth rate (GR): percent change in number of articles published in a domain with respect to previous year, calculated as: $\mathrm{GR}_{\mathrm{n}}=\left[\left(\mathrm{Ndoc}_{\mathrm{n}}-\mathrm{Ndoc}_{\mathrm{n}-1}\right) / \mathrm{Ndoc}_{\mathrm{n}-1}\right]$ * 100, where $n$ is the year[33]

- top ranked journals: in top $25 \%$ (Q1) of journals when ranked in descending order per SCImago Journal \& Country Rank (SJR)[34]

- language of publication: Spanish, English, both

- scientific excellence: inclusion in 10\% most frequently cited articles on diabetes indexed in Scopus[35]

- Cuban scientific leadership: corresponding author affiliated with Cuban institution[36]

- excellence with leadership: percentage of articles led (corresponding author) among 10\% most-cited articles on diabetes indexed in Scopus[37]

- percentage of articles in Q1 journals where corresponding author is affiliated with a Cuban institution

- Cuban leadership: percentage of articles where author affiliations contain addresses in more than one country, and corresponding author is affiliated with a Cuban institution

- percentage of articles with Cuban corresponding author signed by authors in more than one Cuban institution and at least one in a non-Cuban institution

Data retrieval and processing On August 21, 2018, an advanced search was conducted in Scopus using filters by country (Cuba), journal type, article type (original research and review) and year of publication. The search term was "diabetes." The search strategy is displayed in Table 1. For data processing and analysis, records were exported to an ad hoc database using bibliographic reference management software (EndNote $\times 7$ ).

Articles in the $10 \%$ most cited articles on diabetes were obtained using Scival, a bibliographic analysis system from Elsevier. Using the same filters as previously described, Latin American scientific production was obtained for Argentina, Bolivia, Brazil, Chile, Colombia, Costa Rica, Cuba, Dominican Republic, Ecuador, El Salvador, Guatemala, Haiti, Honduras, Mexico, Nicaragua, Panama, Paraguay, Peru, Puerto Rico, Uruguay and Venezuela. The SJR platform was used to categorize journal ranking by quartile. A bibliometric map of scientific cooperation networks among countries was created with VOSviewer v.1.6.5 software,[38] using the full-counting method.[39] Such maps display nodes representing collaborating countries and links connecting these nodes, with link width representing collaboration intensity determined by number of articles.

\begin{tabular}{|c|c|c|}
\hline Operator & Field & Search term \\
\hline & AFFILCOUNTRY & Cuba \\
\hline AND & SRCTYPE & j \\
\hline AND & TITLE-ABS-KEY & diabetes \\
\hline AND & PUBYEAR & $\geq 1999$ \\
\hline AND & LIMIT-TO & $\begin{array}{l}\text { DOCTYPE, "ar" } \\
\text { OR DOCTYPE, "re" }\end{array}$ \\
\hline AND & EXCLUDE & PUBYEAR, 2018 \\
\hline
\end{tabular}

\section{RESULTS}

Production and citation of original research and review articles The Scopus database included 610 articles (538 original research and 72 review articles) with at least 1 Cuban author over the 18-year period under study, with an annual average of 33.9. Annual number of publications grew through 2010 , with 2017 production tripled that of 2000 . Citations rose to 6243 , for an annual average of 346.8. A total of $60 \%$ (366) of articles were cited at least once. The h-index overall for the study period was 34 (Table 2).

Type of article, language of publication and citations Articles in Spanish constituted 67.2\% (410) and received 605 citations (1.5 per article), with an h-index of 8. Articles in English (183, $30 \%)$ were mostly $(119,65 \%)$ published in the final years of the period (2010-2017) and received 5610 citations, with an h-index of 34. The mean number of citations per article was 30.7. As of 2006, the database included publications appearing in both languages, representing $2.5 \%$ of the total (15), with 24 citations and an h-index of 5 (Table 2).

Original research articles The 538 original research articles received 5724 citations, with an average of 10.6 per article and an h-index of 32. A total of 201 original research articles received $1-5$ citations; 40 received $6-10$; 77 received $>10$; and the remaining 220 (40.9\%) were not cited. In other words, 78.3\% of articles received few or no citations. There were 370 (68.8\%) articles published in Spanish, 153 (28.4\%) in English and 13 (2.4\%) in Spanish and English. A single article was published in Portuguese, receiving four citations. Another was published in English and Croatian and was not cited.

Among articles published in Spanish, 159 received $1-5$ citations; 12 received 6-10; 5 received $>10$; and the remaining 194 (52.4\%) were not not cited. Of articles published in English, 35 received $1-5$ citations; 27 received $6-10 ; 72$ received $>10$; and the remaining 19 (12.4\%) were not cited. In summary, 95.4\% of original research articles published in Spanish received few or no citations. The percentage of original research articles published in English and rarely or never cited was $35.3 \%$.

Review articles The 72 review articles received 519 citations with an average of 7.2 per article, and an h-index of 9; 29 articles received $1-5$ citations; 8 received $6-10$ citations; 11 received $>10$ citations; and the remaining 24 (33\%) were not cited. There 
Table 2: Bibliometric indicators of Cuban scientific articles on diabetes (Scopus, 2000-2017)

\begin{tabular}{|c|c|c|c|c|c|c|c|c|c|c|}
\hline Year & $\begin{array}{c}\text { Articles } \\
\mathbf{n}\end{array}$ & $\begin{array}{c}\text { Citations } \\
\mathbf{n}\end{array}$ & $\begin{array}{c}\text { Articles cited } \\
\text { n (\%) }\end{array}$ & $\begin{array}{l}\text { Spanish } \\
\text { articles } \\
\text { (CPA) }\end{array}$ & $\begin{array}{l}\text { English } \\
\text { articles } \\
\text { (CPA) }\end{array}$ & $\begin{array}{l}\text { English and } \\
\text { Spanish }\end{array}$ & h-Index & Excellent ${ }^{\mathrm{a}} \%$ & $\begin{array}{c}\text { Cuban led } \\
\%\end{array}$ & $\begin{array}{c}\text { In Q1 } \\
\text { journals } \\
\%\end{array}$ \\
\hline 2000 & 14 & 52 & 8 (57.1) & $13(1.9)$ & $1(27)$ & 0 & 4 & 0.0 & 100 & 0.0 \\
\hline 2001 & 21 & 153 & $15(71.4)$ & $18(2.3)$ & $3(37.0)$ & 0 & 5 & 0.0 & 100 & 4.8 \\
\hline 2002 & 29 & 145 & $24(82.8)$ & $25(2.8)$ & $4(18.6)$ & 0 & 8 & 0.0 & 100 & 3.5 \\
\hline 2003 & 9 & $1088^{c}$ & $7(77.8)$ & $5(1.6)$ & $4(270.0)$ & 0 & 5 & 11.1 & 77.8 & 22.2 \\
\hline 2004 & 22 & 83 & $15(68.2)$ & 15 (1.9) & $7(7.7)$ & 0 & 6 & 0.0 & 66.7 & 22.7 \\
\hline 2005 & 20 & 702 & $16(80.0)$ & $8(10.4)$ & $12(51.6)$ & 0 & 11 & 10.0 & 85.0 & 25.0 \\
\hline 2006 & 33 & 707 & $15(45.4)$ & $26(0.7)$ & $6(114.8)$ & 1 & 6 & 6.1 & 81.8 & 12.1 \\
\hline 2007 & 30 & 280 & $18(60.0)$ & $23(2.0)$ & 7 (33.4) & 0 & 7 & 3.3 & 80.0 & 3.3 \\
\hline 2008 & 34 & 620 & $24(70.6)$ & $25(1.6)$ & $9(64.6)$ & 0 & 7 & 5.9 & 85.3 & 11.8 \\
\hline 2009 & 40 & 491 & $27(67.5)$ & $29(1.8)$ & $11(39.8)$ & 0 & 8 & 5.0 & 77.5 & 7.5 \\
\hline 2010 & 45 & 188 & $28(62.2)$ & 33 (1.1) & 8 (18.4) & 4 & 6 & 0.0 & 95.6 & 6.7 \\
\hline 2011 & $38^{d}$ & 246 & $23(60.5)$ & 25 (1.7) & $12(16.7)$ & 0 & 7 & 0.0 & 89.5 & 10.5 \\
\hline 2012 & 50 & 159 & $30(60.0)$ & $36(1.2)$ & $12(9.7)$ & 2 & 6 & 0.0 & 90.0 & 8.0 \\
\hline 2013 & 55 & 328 & 39 (70.9) & 29 (1.3) & $24(12.0)$ & 2 & 9 & 0.0 & 81.8 & 16.4 \\
\hline 2014 & $43^{d}$ & 300 & $30(69.8)$ & $22(1.0)$ & $17(5.9)$ & 3 & 10 & 0.0 & 81.4 & 14.0 \\
\hline 2015 & 49 & 335 & $22(44.9)$ & $33(0.5)$ & $16(19.9)$ & 0 & 5 & 2.0 & 83.7 & 6.1 \\
\hline 2016 & 35 & 324 & $13(37.1)$ & $18(0.1)$ & 15 (21.5) & 2 & 6 & 2.9 & 80.0 & 22.9 \\
\hline 2017 & 43 & 42 & $12(27.9)$ & $27(0.1)$ & $15(2.6)$ & 1 & 4 & 0.0 & 88.4 & 11.3 \\
\hline Overall & $610^{d}$ & 6243 & $366(60.0)$ & 410 (1.5) & $183(30.0)$ & 15 & 34 & 2.0 & 85.9 & 11.1 \\
\hline
\end{tabular}

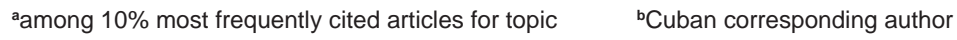

"A US clinical trial on hypertension with keyword "diabetes" accounts for spike in citations darticles in other languages not included in horizontal totals CPA: citations per article

were $35(48.6 \%)$ articles published in Spanish, $30(41.7 \%)$ in English and $2(2.8 \%)$ in both languages. Of articles published in Spanish, 14 received $1-5$ citations; 3 received $6-10$; and the remaining 18 (51.1\%) were not cited. Of articles published in English, 11 received $1-5$ citations; 5 received $6-10 ; 11$ received $>10$; and $3(10 \%)$ were not cited. A total of $91.4 \%$ of review articles in Spanish received no or very few citations, as did $46.7 \%$ of those published in English.

Scientific collaboration, excellence and leadership Scientific collaboration was analyzed with regard to production volume and article impact, expressed by number of citations (Table 2). Nearly half $(287,47 \%)$ of Cuba's scientific production on diabetes was from a single Cuban institution (i.e., without any external collaboration); these articles received 540 citations (8.6\% of total). A total of $183(30 \%)$ articles were published in collaborations involving authors from several Cuban institutions, most $(116,63.4 \%)$ in the final 8 years under study (2010-2017). Work conducted and published with international collaboration accounted for $22.3 \%$ of the total; $52.2 \%$ of articles had both Cuban and international collaboration; and $25.5 \%$ were produced by a single Cuban institution.

A total of $85.9 \%$ of articles named a Cuban as corresponding author. Cubans were corresponding authors in 32.1\% (45/140) of articles published with international participation. Two articles (0.3\%) deemed excellent (top $10 \%$ in citation frequency) had Cuban leadership; they were published in 2005 and 2015 (Table 2). The 94 articles published by a single Cuban institution in collaboration with non-Cuban institutions represented $15.4 \%$ of the total but received $64.8 \%$ of citations (4046). A total of $77.7 \%$ of these articles had a non-Cuban corresponding author. Works published by more than one Cuban institution and with international collaboration $(46,7.5 \%)$ received $12.6 \%$ of all citations; of these, $47.8 \%$ had a non-Cuban corresponding author (Table 3).

Cuban contributions to international production, rates of increase, $\mathrm{h}$-index and publications in top-ranked journals The volume of global production on diabetes in Scopus during the period studied amounted to 457,681 articles. Scientific production from Latin America during the period totaled 19,268 articles, for an annual average of 1070.4. Cuba was responsible for 3.2\% of Latin American and $0.1 \%$ of global production. Within Latin America, Cuba ranked 6th in number of articles published over the full period, surpassed by Brazil $(9850,51.1 \%)$, Mexico (3822, 19.8\%), Argentina (1760, 9.1\%), Chile $(1235,6.4 \%)$ and Colombia $(745$, $3.9 \%$ ). Cuba ranked fifth in 2000-2008, and also in 2010. In 2008, Cuba shared the 5th-rank position with Colombia (34 articles). In 2009, Cuba was displaced from fifth to sixth by Colombia and stayed in that position in 2011-2015, and in 2017. In 2016, Cuba ranked seventh, after Peru. In terms of h-index values during the years studied, in Latin America, Cuba ranked 8th, along with Peru $(h=34)$, and behind Brazil $(h=159)$, Mexico $(h=116)$, Argentina $(h=98)$, Chile $(h=77)$, Colombia $(h=63)$, Venezuela $(h=39)$ and Puerto Rico $(h=38)$.

Over the 18 years covered by the study, global scientific production on diabetes increased steadily (with the exception of 2017), with an average annual growth rate of $8.3 \%$. Annual production increased from 10,278 articles in 2000 to 38,238 in 2017. In Latin America, the 240 articles published in 2000 increased to 2019 by the year 2017, an average annual growth rate of $14.2 \%$, which is much higher than the global average. In contrast to Latin America, where annual growth rates never dipped into negative values, in Cuba, the years 2000, 2003, 2005, 2007, 2011, 2014 and 2016 had negative growth rates (Figure 1 ). 
Table 3: Articles by type of scientific collaboration and impact in citations (Scopus, 2000-2017)

\begin{tabular}{|c|c|c|c|c|c|c|c|c|c|c|c|}
\hline \multirow{2}{*}{ Year } & \multicolumn{2}{|c|}{ No collaboration } & \multicolumn{2}{|c|}{$\begin{array}{c}\text { National } \\
\text { collaboration }\end{array}$} & \multicolumn{3}{|c|}{$\begin{array}{l}\text { International } \\
\text { collaboration }\end{array}$} & \multicolumn{3}{|c|}{$\begin{array}{c}\text { International and } \\
\text { national collaboration }\end{array}$} & \multirow{2}{*}{$\begin{array}{c}\text { Cuban led } \\
\text { International } \\
\text { and national } \\
+ \text { international* }\end{array}$} \\
\hline & $\begin{array}{c}\text { Articles } \\
\text { n }\end{array}$ & $\begin{array}{c}\text { Citations } \\
\mathrm{n}\end{array}$ & $\begin{array}{c}\text { Articles } \\
\mathrm{n}\end{array}$ & $\begin{array}{c}\text { Citations } \\
\mathrm{n}\end{array}$ & $\begin{array}{c}\text { Articles } \\
\mathrm{n}\end{array}$ & $\begin{array}{c}\text { Citations } \\
\mathrm{n}\end{array}$ & $\begin{array}{c}\text { Cuban led* } \\
\%\end{array}$ & $\begin{array}{c}\text { Articles } \\
\mathrm{n}\end{array}$ & $\begin{array}{c}\text { Citations } \\
\mathrm{n}\end{array}$ & $\begin{array}{c}\text { Cuban led* } \\
\%\end{array}$ & \\
\hline 2000 & 11 & 24 & 3 & 28 & 0 & - & - & 0 & - & - & - \\
\hline 2001 & 16 & 81 & 4 & 11 & 0 & 一 & - & 1 & 61 & 100 & 100 \\
\hline 2002 & 19 & 69 & 8 & 60 & 2 & 16 & 100 & 0 & - & - & 0.0 \\
\hline 2003 & 4 & 8 & 2 & 22 & 2 & 1014 & 0.0 & 1 & 44 & 100 & 33.3 \\
\hline 2004 & 8 & 17 & 6 & 26 & 8 & 40 & 12.5 & 0 & - & - & 12.5 \\
\hline 2005 & 6 & 17 & 6 & 157 & 5 & 285 & 60.0 & 3 & 243 & 100 & 75.0 \\
\hline 2006 & 21 & 17 & 5 & 40 & 6 & 635 & 0.0 & 1 & 15 & 100 & 14.3 \\
\hline 2007 & 13 & 31 & 10 & 125 & 6 & 123 & 16.7 & 1 & 1 & 0.00 & 14.3 \\
\hline 2008 & 19 & 25 & 8 & 41 & 5 & 456 & 20.0 & 2 & 98 & 50.0 & 28.6 \\
\hline 2009 & 15 & 37 & 15 & 85 & 9 & 362 & 11.1 & 1 & 7 & 100 & 20.0 \\
\hline 2010 & 26 & 28 & 15 & 58 & 2 & 101 & 0.0 & 2 & 1 & 100 & 50.0 \\
\hline 2011 & 21 & 52 & 10 & 74 & 3 & 98 & 33.3 & 4 & 22 & 50.0 & 42.9 \\
\hline 2012 & 17 & 17 & 24 & 41 & 7 & 54 & 42.9 & 2 & 47 & 50.0 & 44.4 \\
\hline 2013 & 24 & 86 & 16 & 58 & 11 & 159 & 27.3 & 4 & 25 & 50.0 & 33.3 \\
\hline 2014 & 15 & 18 & 13 & 26 & 8 & 127 & 37.5 & 7 & 129 & 42.9 & 40.0 \\
\hline 2015 & 23 & 7 & 11 & 6 & 7 & 263 & 28.6 & 8 & 59 & 25.0 & 26.7 \\
\hline 2016 & 12 & 0 & 10 & 11 & 10 & 304 & 20.0 & 3 & 9 & 33.3 & 23.1 \\
\hline 2017 & 17 & 6 & 17 & 1 & 3 & 9 & 33.3 & 6 & 26 & 50.0 & 40.0 \\
\hline Overall & 287 & 540 & 183 & 870 & 94 & 4046 & 22.3 & 46 & 787 & 52.2 & 32.1 \\
\hline
\end{tabular}

*Cuban corresponding author

Some $11.1 \%$ (68) of Cuban-authored articles on diabetes were published in Q1 journals, 45 of them in 2009-2017 (Table 3). These articles received 4143 citations, representing $66.3 \%$ of all citations, for an average of 60.9 citations per article and an h-index of 26. All were published in English and 22 (32.4\% of Cuban-authored articles in Q1) had a Cuban corresponding author. A total of $12.5 \%$ (76) of all articles were published in Q2 journals. These received 1104 citations, accounting for $17.7 \%$ of the total, with an average of 14.5 citations per article and an h-index of 19; $98.7 \%$ (75) of them were published in English. Some 232 (38\%) were published in Q3 journals and received 642 citations, accounting for $10.3 \%$ of total citations, with an average of 2.8 citations per article and an h-index of 13 . Of these, 20

Figure 1: Annual growth of global, Latin American and Cuban scientific production on diabetes (Scopus, 2000-2017)

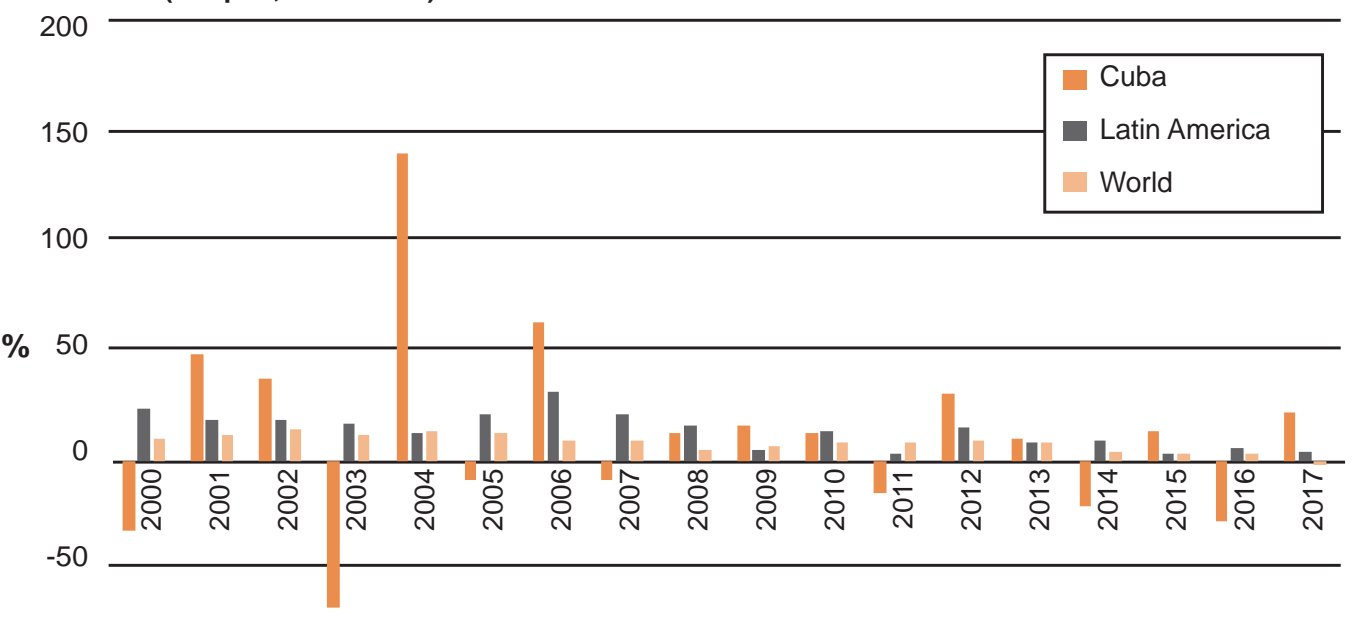

articles (8.6\%) were published in English. The remaining 234 articles (38.4\%) were published in Q4 journals and received 354 citations (5.7\% of all citations received), with an h-index of 7. Language of publication was English for 17 of these articles (7.3\%).

Cuban authors were published in 174 journals, 12 of which published $\geq 10$ articles on diabetes ( 1 in Q2, 6 in Q3, and 5 in Q4). Cuban journals accounted for 353 articles (57.9\%), of which 170 were cited (414 citations) at least once. Articles published in Cuban journals received $6.6 \%$ of citations-more than half (183) were not cited-with an h-index of 8. The greatest volume of production (158) was found in Revista Cubana de Medicina General Integral, Revista Cubana de Investigaciones Biomédicas and Revista Cubana de Medicina, together accounting for $25.9 \%$ of all articles. Corresponding authors were Cuban for all articles in the 12 journals that published $\geq 10$ research articles (Table 4).

With regard to impact (in terms of citations) of articles in journals with $\geq 10$ articles published, MEDICC Review was the journal with the greatest number of citations and highest h-index (346, 11.2 citations per article and $h=10$ ) and the only non-Cuban journal with $\geq 10$ articles retrieved. The highest percentage of scientific 
Table 4: Journals publishing $\geq 10$ Cuban-authored articles on diabetes (Scopus, 2000-2017)

\begin{tabular}{|c|c|c|c|c|c|c|c|c|c|}
\hline Journal & Country & Quartile $^{a}$ & $\begin{array}{c}\text { Articles } \\
n\end{array}$ & $\begin{array}{c}\text { Citations } \\
n\end{array}$ & $\begin{array}{l}\text { Articles cited } \\
\text { n (\%) }\end{array}$ & CPA & H-index & $\begin{array}{c}\text { Collaboration }^{\mathrm{b}} \\
\%\end{array}$ & $\begin{array}{c}\text { Cuban led } \\
\%\end{array}$ \\
\hline $\begin{array}{l}\text { Revista Cubana de Medicina General } \\
\text { Integral }\end{array}$ & Cuba & Q3 & 57 & 81 & $34(59.7)$ & 1.4 & 4 & 35.1 & 98.3 \\
\hline $\begin{array}{l}\text { Revista Cubana de Investigaciones } \\
\text { Biomédicas }\end{array}$ & Cuba & Q4 & 51 & 80 & $32(62.7)$ & 1.6 & 4 & 39.2 & 98.0 \\
\hline Revista Cubana de Medicina & Cuba & Q4 & 50 & 38 & $19(38.0)$ & 0.8 & 3 & 26.0 & 100 \\
\hline MEDICC Review & USA & Q2 & 31 & 346 & $25(80.7)$ & 11.2 & 10 & 71.0 & 90.3 \\
\hline $\begin{array}{l}\text { Revista Habanera de Ciencias } \\
\text { Médicas }\end{array}$ & Cuba & Q3 & 31 & 22 & $11(35.5)$ & 0.7 & 3 & 29.0 & 100 \\
\hline Revista Cubana de Medicina Militar & Cuba & Q3 & 30 & 19 & $9(30.0)$ & 0.6 & 3 & 10.0 & 100 \\
\hline $\begin{array}{l}\text { Revista Cubana de Obstetricia y } \\
\text { Ginecología }\end{array}$ & Cuba & Q3 & 26 & 30 & $13(50.0)$ & 1.2 & 3 & 38.5 & 100 \\
\hline Biotecnología Aplicada & Cuba & Q4 & 16 & 47 & $11(68.8)$ & 2.9 & 4 & 68.8 & 100 \\
\hline Revista Cubana de Salud Pública & Cuba & Q3 & 16 & 15 & $9(56.2)$ & 0.9 & 2 & 62.5 & 100 \\
\hline Revista Cubana de Cirugía & Cuba & Q4 & 14 & 5 & $4(28.6)$ & 0.4 & 1 & 14.3 & 100 \\
\hline $\begin{array}{l}\text { Revista Cubana de Higiene } \\
\text { y Epidemiología }\end{array}$ & Cuba & Q4 & 12 & 24 & $8(66.7)$ & 2.0 & 3 & 58.3 & 100 \\
\hline Revista Cubana de Pediatría & Cuba & Q3 & 10 & 20 & $4(20.0)$ & 2.0 & 3 & 70.0 & 100 \\
\hline
\end{tabular}

Figure 2: Scientific collaboration networks among countries with $\geq 3$ articles published with Cuban researchers (Scopus, 2000-2017)

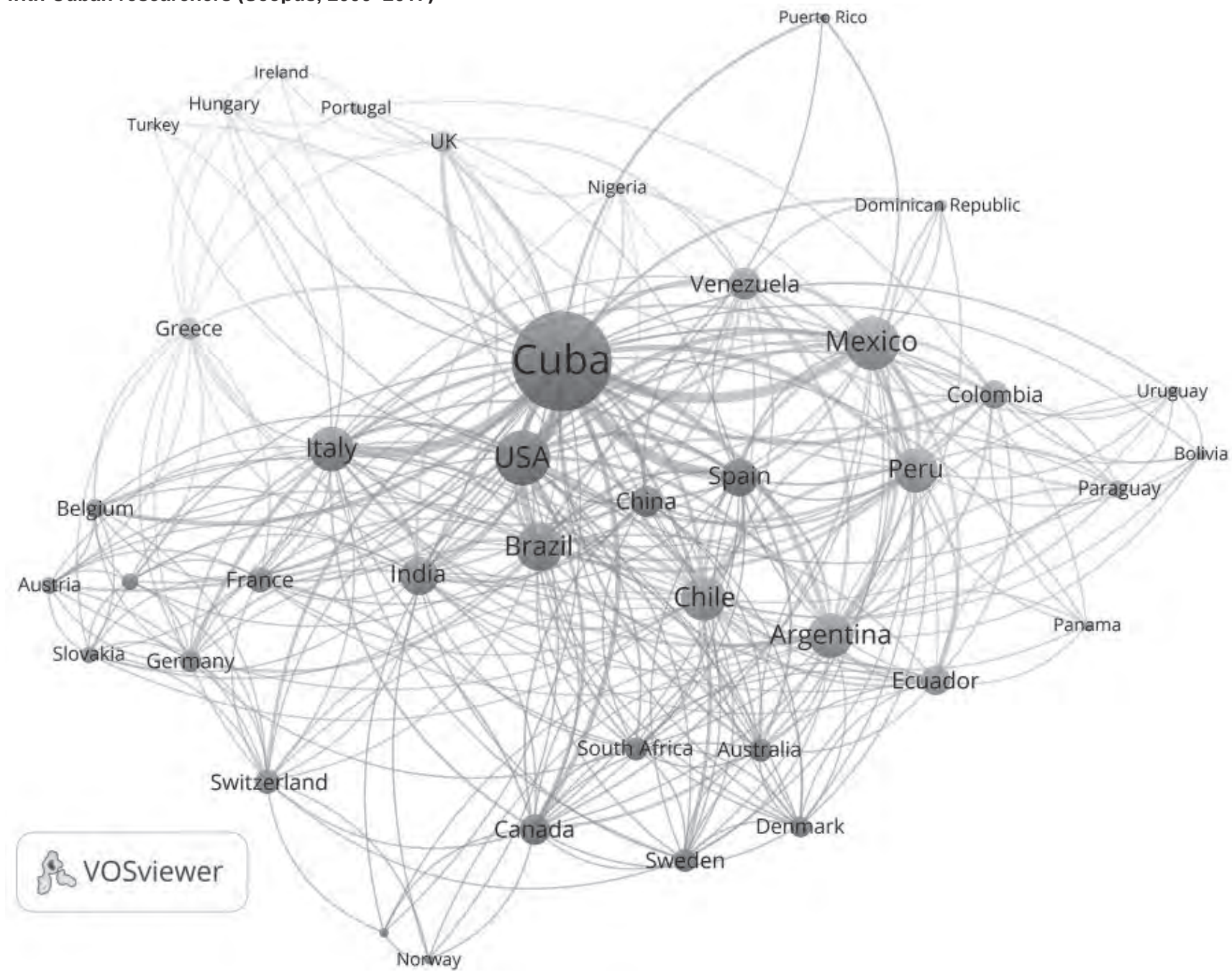

(available in color online at www.mediccreview.org/cuban-scientific-production-on-diabetes-2000-2017) 
collaboration of any type was found in MEDICC Review (71\%), followed by the Revista Cubana de Pediatría (70\%) (Table 4).

Production of articles deemed excellent was scant. In 10 of the 18 years under study, none was reported (Table 2). Works deemed excellent appeared in the following journals: American Journal of Epidemiology, American Journal of Medicine, American Journal of Obstetrics and Gynecology, BMC Complementary and Alternative Medicine, Circulation Research, Journal of the American Medical Association, Journal of Physiology, The Lancet, Gastroenterology, and European Journal of Pharmacology. Articles in the latter two journals had a Cuban corresponding author (excellence with Cuban leadership).

Collaboration networks Cuban authors published with researchers from 34 countries, most frequently the USA (36 articles), Spain (26), Italy (24), Mexico (24), Brazil (13), Argentina (10), and Peru (9). Figure 2 presents a bibliometric map of scientific collaboration networks among countries, with a threshold of three or more coauthored articles published. The diagram shows a central nucleus of densely connected countries surrounded by countries with fewer connections. The countries fall into five clusters. Cuba, USA, Spain, Italy and Mexico are the main nodes, with the greatest number of coauthored articles. The most prolific networks of scientific collaboration exist between Cuban and US researchers.

\section{DISCUSSION}

Critical analysis is key to interpreting bibliometric indicators. For example, the figures for Cuban leadership are redundant for articles entirely authored by Cubans but are of great interest when analyzing articles with international collaboration. Combined analysis of number of citations by publication language that simultaneously takes into account journal quartile and international collaboration is much more informative than the overall numbers yielded by the search. The study initially detected 115 articles published in Spanish and English. After critical examination, this number was reduced to 15 . The overrepresentation was due to the fact that articles with abstracts in two languages were included in the database. The atypical number of citations in 2003 reflects a Cuban-authored article with keyword "diabetes" with content unrelated to the search topic-It was actually about a clinical trial on hypertension.

Production of Cuban articles in the medical sciences is lower than might be expected given the country's human capital and research capabilities and contains scarcely any articles from the primary health sector, the foundation of Cuba's universal health system. $[40,41]$ For Benet, this poses cause for concern, as the residency in family medicine (the specialty of the majority of new medical graduates) requires a thesis.[42] Master's and doctoral degrees also require scientific publication. Given the 18-year period under analysis and the high number of Cuban health sciences students and professionals (totaling 192,596 in the 2017-2018 academic year, according to the 2017 Health Statistics Yearbook),[15] one could expect high productivity in terms of articles published in indexed scientific journals.

This study demonstrates shortcomings in Cuban medical publishing on diabetes in terms of visibility and impact. For scientific production on diabetes to reflect Cuban outcomes in prevention, diagnostics and treatment, Cuban researchers would need to publish in journals with greater visibility. For example, in years with the greatest number of publications on this topic, $\mathrm{h}$-indexes were very low. Limited publication in Q1 journals is observed in other branches of Cuban science and is not specific to the health sciences. $[33,40,41]$ The scientific literature does not yet adequately reflect the Cuban health system's strategies, research, product development or outcomes.

Cuban researchers and administrators are far from demonstrating the results of their daily work and research in top-ranked scientific publications. [43] It has been noted that low production of scientific articles might be influenced by the absence of a culture of publication, insufficient training in scientific writing, and the (understandable) existence of other priorities, such as teaching and patient care, which account for the greatest share of professional responsibilities and time.[41] We agree with Zacca-González, who notes the need for strategies to promote publication in top-ranked journals while seeking a balance between articles published in Cuban journals and those published in non-Cuban journals.[44]

Over the period, Cuban scientific production showed a tendency to stagnate, in contrast to global trends[16-21,27,29,45-47] and those of countries such as Nigeria,[26] China[30] and Peru.[31] The number of articles retrieved from Scopus increased when Cuban journals from SciELO were included, but the total number of citations decreased, as did the h-index.[44,48] Cuba ranks sixth in Latin America in number of articles published, which is impressive when taking into account the size of our population and the US embargo. But Cuba's position in term of its $\mathrm{h}$-index is less satisfactory, and its eighth-place position in Latin America is difficult to explain.

We believe Cuban journals should redouble their efforts to recruit high-level international peer reviewers. External peer review by international experts can contribute substantially to article quality and is a free source of instruction and scientific debate that allows us to assess our research quality by international standards.

Authors from Cuba published as coauthors with researchers from 34 countries, with the USA leading the list. In recent decades, there has been a notable increase in scientific collaboration,[49] influenced by multidisciplinary and increasingly specialized research. This brings additional benefits in terms of citations and impact.[50] Among the obvious benefits of international collaboration is the possibility of participating in international research, with its access and contributions to the collective knowledge of key experts, state-of-the-art treatments and technologies, and ongoing research programs.[51]

As noted in other studies,[52,53] articles published with international collaboration achieved, on average, greater impact in terms of citations than those produced with only Cuban or no collaboration. The likely reasons for this are the increased number of informal and formal channels for dissemination, publication in the top-ranked journals, superior research quality (in some cases), or the importance beyond local horizons of its subject matter-factors of greater interest to the international scientific community. Narin found that publications by scientists affiliated with institutions connected to more than one country in the European Union were cited twice as often as articles written by scientists working in a single institution within a single country. 
Narin concludes that national collaboration increases the volume of citations by a factor of 1.5 , whereas international collaboration increases it by a factor of 2.5.[54] The extraterritorial nature of the US economic, financial and trade embargo in effect since 1962 has been an obstacle not only to greater bilateral research collaboration and publishing but has also limited contact with other countries' researchers.[55]

Cuban leadership in articles published with international collaboration was found to be low, perhaps because these are international research projects generated and led by nonCuban entities. Involvement with international institutions in research areas led by Cuban entities strengthens our national capacity, particularly in activities involving training for human resources and the acquisition of technology.[56-58]

Many Cuban professors and specialists do collaborative medical work in other countries, especially in Latin America and Africa, but this extensive collaboration has not been translated into the production of scientific articles in this field.[48] Cuba is home to the Latin American School of Medicine, which to date has trained some 30,000 health professionals from around the world. These professionals could be a valuable source of publishable experiences, in collaboration with Cuban specialists or entities. It would make sense to include scientific writing and publishing in its curriculum, and to encourage students to undertake research projects linked to medical practice in their communities. We agree with Zacca-González,[44,48] who believes that conditions exist to create collaborative networks and achieve greater impact and visibility for Cuban scientific research.

Study limitations Samples obtained in this study might include articles without diabetes as a main topic, despite having the term "diabetes" in their descriptors. A more restrictive strategy, such as searching in indexed journals under the thematic category "Endocrinology, Diabetes and Metabolism" in the Scopus database, would have meant ignoring a great amount of diabetes research published in multidisciplinary journals or found in other thematic categories. Nor did the study characterize the main themes of scientific research on diabetes in Cuba. This could be the topic of future studies.

\section{CONCLUSIONS}

The volume of publications on diabetes by Cuban authors illustrates that diabetes motivates research by Cuban scientists and institutions but their work is insufficiently reflected in the peerreviewed literature, particularly top-ranked journals. We urgently need to change this situation. The current problem is not simply one of publishing more, but of knowing how and where to publish. It is urgent that Cuban universities training professionals at all levels of health care include instruction on writing for publication in peer-reviewed journals. -1 p-

\section{REFERENCES}

1. Carndarll J, Shamoon H. In: Goldman-Cecil, editor. Tratado de Medicina Interna. Madrid: Elsevier; 2017. Chapter 229, Diabetes mellitus; p.1527-48. Spanish.

2. Zhu M, Li J, Li Z, Luo W, Dai D, Weaver SR. Mortality rates and the causes of death related to diabetes mellitus in Shanghai Songjiang District: an 11-year retrospective analysis of death certificates. BMC Endocr Disord [Internet]. 2015 Sep 4 [cited 2018 Aug 24];15:45. Available from: http:// dx.doi.org/10.1186/s12902-015-0042-1

3. Geiss LS, Wang J, Cheng YJ, Thompson TJ, Barker L, Li Y, et al. Prevalence and incidence trends for diagnosed diabetes among adults aged 20 to 79 years, United States, 1980-2012. JAMA [Internet]. 2014 Sep 24 [cited 2018 Aug 24];312(12):1218-26. Available from: https://jama network.com/journals/jama/fullarticle/10.1001/ jama.2014.11494

4. Tarekegne FE, Padyab M, Schröders J, Stewart J. Sociodemographic and behavioral characteristics associated with self-reported diagnosed diabetes mellitus in adults aged 50 years in Ghana and South Africa: results from the WHO-SAGE wave. BMJ Open Diabetes Res Care [Internet]. 2018 Feb 2 [cited 2018 Aug 24];6(1):e000449. Available from: http://dx.doi.org/10.1136/bmjdrc -2017-000449

5. Ghosh N, Katare R. Molecular mechanism of diabetic cardiomyopathy and modulation of microRNA function by synthetic oligonucleotides. Cardiovasc Diabetol [Internet]. 2018 Mar 22 [cited 2018 Aug 24];17(1):43. Available from: http://dx.doi.org/10.1186/s12933-018-0684-1

6. Ten Klooster JP, Sotiriou A, Boeren S, Vaessen $\mathrm{S}$, Vervoort J, Pieters R. Type 2 diabetes-related proteins derived from an in vitro model of inflamed fat tissue. Arch Biochem Biophys [Internet]. 2018 Apr 15 [cited 2018 Aug 24];644:81-92. Available from: http://dx.doi.org/10.1016/j.abb .2018.03.003
7. Al-Ghamdi AH, Fureeh AA. Prevalence and clinical presentation at the onset of type 1 diabetes mellitus among children and adolescents in ALBaha region, Saudi Arabia. J Pediatr Endocrinol Metab [Internet]. 2018 Mar 28 [cited 2018 Aug 24];31(3):269-73. Available from: http://dx.doi.org/ 10.1515/jpem-2017-0059

8. Forbes JM, Fotheringham, AK. Vascular complications in diabetes: old messages, new thoughts. Diabetologia [Internet]. 2017 Nov [cited 2018 Aug 24];60(11):2129-38. Available from:https://doi.org/ 10.1007/s00125-017-4360-x

9. Cho NH, Shaw JE, Karuranga S, Hung $\mathrm{Y}$, da Rocha Fernandes JD, Ohlrogge Aw, et al. IDF Diabetes Atlas: global estimates of diabetes prevalence for 2017 and projections for 2045. Diabetes Res Clin Pract [Internet]. 2018 Apr [cited 2018 Sep 16];138:271-81. Available from: http:// dx.doi.org/10.1016/j.diabres.2018.02.023

10. da Rocha Fernandes J, Ogurtsova K, Linnenkamp U, Guariguata L, Seuring T, Zhang P, et al. IDF Diabetes Atlas estimates of 2014 global health expenditures on diabetes. Diabetes Res Clin Pract [Internet]. 2016 Jul [cited 2018 Aug 24];117:48-54. Available from: http://dx.doi.org/ 10.1016/j.diabres.2016.04.016

11. Guariguata L, Whiting DR, Hambleton I, Beagley J, Linnenkamp U, Shaw JE. IDF Diabetes Atlas. Global estimates of diabetes prevalence for 2013 and projections for 2035. Diabetes Res Clin Prac [Internet]. 2014 Feb [cited 2018 Aug 20];103(2):137-49. Available from: http://dx.doi .org/10.1016/j.diabres.2013.11.002

12. Agudelo-Botero M, Dávila-Cervantes CA. Carga de la mortalidad por diabetes mellitus en América Latina 2000-2011: los casos de Argentina, Chile, Colombia y México. Gac Sanit. 2015 May-Jun [cited 2018 Aug 20];29(3):172-7. Available from: http:// dx.doi.org/10.1016/j.gaceta.2015.01.015. Spanish.

13. Vargas-Uricoechea $\mathrm{H}$, Casas-Figueroa LÁ. Epidemiología de la diabetes mellitus en Suda- mérica: la experiencia de Colombia. Clín Investig Arterioscler [Internet]. 2016 Sep-Oct [cited 2018 Aug 24];28(5):245-56. Available from: https://doi .org/10.1016/j.arteri.2015.12.002. Spanish.

14. Sapunar J. Epidemiología de la diabetes mellitus en Chile. Rev Med Clin Condes [Internet]. 2016 Mar [cited 2018 Aug 20];27(2):146-51. Available from: https://www.sciencedirect.com/science/article/ pii/S0716864016300037. Spanish.

15. National Health Statistics and Medical Records Division (CU). Anuario Estadístico de Salud 2017 [Internet]. Havana: Ministry of Public Health (CU); 2018 [cited 2018 Aug 24]. Available from: http:// files.sld.cu/dne/files/2018/04/Anuario-Electro nico-Espa\%C3\%B1ol-2017-ed-2018.pdf. Spanish.

16. Michán L, Muñoz-Velasco I. Cienciometría para ciencias médicas: definiciones, aplicaciones y perspectivas. Inv Ed Med [Internet]. $2013 \mathrm{Apr}-\mathrm{Jun}$ [cited 2018 Aug 24];2(6):100-6. Available from: http://www.scielo.org.mx/scielo.php?pid=S2007 $-50572013000200006 \&$ script=sci_arttext. Spanish.

17. $\mathrm{Pu} \mathrm{QH}$, Lyu QJ, Liu $\mathrm{H}$, Fan $\mathrm{KH}$. Bibliometric analysis of the top-cited articles on islet transplantation. Medicine (Baltimore) [Internet]. 2017 Nov [cited 2018 Aug 24];96(44):e8247. Available from: http://dx.doi.org/10.1097/MD .0000000000008247

18. Gao Y, Wang Y, Zhai X, He Y, Chen R, Zhou J, et al. Publication trends of research on diabetes mellitus and T cells (1997-2016): A 20-year bibliometric study. PLoS One [Internet]. 2017 Sep 19 [cited 2018 Aug 24];12(9):e0184869. Available from: http://dx.doi.org/10.1371/journal. pone.0184869

19. Tian J, Li M, Lian F, Tong $X$. The hundred most-cited publications in microbiota of diabetes research: a bibliometric analysis. Medicine (Baltimore) [Internet]. 2017 Nov [cited 2018 Aug 24];96(37):e7338. Available from: http://dx.doi .org/10.1097/MD.0000000000007338 
20. Geaney F, Scutaru C, Kelly C, Glynn RW, Perry IJ. Type 2 diabetes research yield, 1951-2012: bibliometrics analysis and density-equalizing mapping. PLoS One [Internet]. 2015 Jul 24 [cited 2018 Aug 24];10(7):e0133009. Available from: https://doi.org/10.1371/journal.pone.0133009

21. Brüggmann $D$, Richter $T$, Klingelhöfer $D$, Gerber A, Bundschuh A, Jaque J, et al. Global architecture of gestational diabetes research: density-equalizing mapping studies and gender analysis. Nutr J [Internet]. 2016 Apr 4 [cited 2018 Aug 24];15:36. Available from: http://dx.doi .org/10.1186/s12937-016-0154-0

22. SweilehWM, Zyoud SH, Al-Jabi SW, Sawalha AF. Bibliometric analysis of diabetes mellitus research output from Middle Eastern Arab countries during the period (1996-2012). Scientometrics [Internet]. 2014 Oct [cited 2018 Aug 24];101(1):819-32. Available from: https://doi .org/10.1007/s11192-014-1361-0

23. Peykari N, Djalalinia S, Kasaeian A, Naderimagham S, Hasannia T, Larijani B, et al. Diabetes research in Middle East countries; a scientometrics study from 1990 to 2012. J Res Med Sci [Internet]. 2015 Mar [cited 2018 Aug 24];20(3):253. Available from: https://www.ncbi .nlm.nih.gov/pmc/articles/PMC4468230/

24. Rasolabadi M, Khaledi S, Ardalan M, Kalhor MM, Penjvini S, Gharib A. Diabetes research in Iran: a scientometric analysis of publications output. Acta Inform Med [Internet]. 2015 Jun [cited 2018 Aug 24];23(3):160-4. Available from: https:// dx.doi.org/10.5455/aim.2015.23.160-164

25. Nasli-Esfahani E, Farzadfar F, Kouhnavard M, Ghodssi-Ghassemabadi R, Khajavi A, Peimani $M$, et al. Iran diabetes research roadmap (IDRR) study: a preliminary study on diabetes research in the world and Iran. J Diabetes Metab Disord [Internet]. 2017 Feb 17 [cited 2018 Aug 24];16:9. Available from: http://dx.doi.org/10.1186/s40200 -017-0291-9

26. Harande YI. Exploring the literature of diabetes in Nigeria: a bibliometrics study. Afr J Diabetes Med [Internet]. 2011 Nov [cited 2018 Aug 24];19(2):811. Available from: http://www.africanjournalof diabetesmedicine.com/articles/november_2011/ Literature of diabetes.pdf

27. Harande YI, Alhaji IU. Basic literature of diabetes: a bibliometrics analysis of three countries in different world regions. J Lib Inf Sci [Internet]. 2014 [cited 2018 Aug 24];2(1):49-56. Available from: http://jlisnet.com/journals/jlis/Vol_2_No_1 _March_2014/6.pdf

28. Bala A, Gupta BM. Diabetes research in India, China and Brazil: a comparative quantitative study, 2000-09. J Adv Lib Inf Sci [Internet]. 2012 Apr-Jun [cited 2018 Aug 24];1(2):69-78. Available from: https://jalis.in/ pdf/pdf_27jun/20121204.pdf

29. Gupta BM, Kaur H, Bala A. Mapping of Indian diabetes research during 1999-2008: a scientometric analysis of publications output. DESIDOC J Library Inf Tech [Internet]. 2011 Mar [cited 2018 Aug 24];31(2):143-52. Available from: http://pub lications.drdo.gov.in/ojs/index.php/djlit/article/ view/866

30. Zhao X, Guo L, Yuan M, He X, Lin Y, Gu C, et al. Growing trend of China's contribution to global diabetes research. A systematic literature review. Medicine [Internet]. 2016 May [cited 2018 Aug 24];95(18):e3517. Available from: http://dx.doi .org/10.1097/MD.0000000000003517

31. Taype-Rondan A, Huapaya-Huertas O, BendezuQuispe G, Pacheco-Mendoza J, Bryce-Alberti M. Producción científica en diabetes en Perú: un estudio bibliométrico. Rev Chil Nutr [Internet]. 2017 [cited 2018 Aug 24];44(2):153-60. Available from: http://dx.doi.org/10.4067/S0717 -75182017000200006 . Spanish.
32. Hirsch JE. An index to quantify an individual's scientific research output. Proc Natl Acad Sci USA [Internet]. 2005 Nov 15 [cited 2018 Aug 24];102(46):16569-72. Available from: http:// dx.doi.org/10.1073/pnas.0507655102

33. Zacca González G. Producción científica latinoamericana en Salud Pública. Cuba en el contexto regional. Scopus 2003-2011 [Internet] [thesis]. [Granada]: Universidad de Granada; 2015 May [cited 2018 Aug 24]. 224 p. Available from: http:// hdl.handle.net/10481/40902. Spanish.

34. González-Pereira B, Guerrero-Bote VP, de Moya-Anegón F. A new approach to the metric of journal's scientific prestige: The SJR indicator. J Informetr [Internet]. 2010 Jul [cited 2018 Aug 24];4(3):379-91. Available from: https://doi .org/10.1016/j.joi.2010.03.002

35. Bornmann L, de Moya-Anegón F, Leydesdorff L. The new excellence indicator in the World Report of the SCImago Institutions Rankings 2011. J Informetr [Internet]. 2012 [cited 2018 Aug 24];6(2):333-5. Available from: https://arxiv.org/ abs/1110.2305

36. de Moya-Anegón F, Guerrero-Bote VP, Bortmann $L$, Moed HF. The research guarantors of scientific papers and the output counting: a promising new approach. Scientometrics [Internet]. 2013 Nov [cited 2018 Aug 24];97(2):421-34. Available from: https://doi.org/10.1007/s11192-013-1046-0

37. Jeremić $\mathrm{V}$, Jovanović-Milenković $\mathrm{M}$, Radojičić $\mathrm{Z}$, Martić M. Excellence with leadership: the crown indicator of Scimago Institutions Rankings Iber Report. Prof Inf [Internet]. 2013 Sep-Oct [cited 2018 Aug 24];22(5):474-80. Available from: http://dx.doi.org/10.3145/epi.2013.sep.13

38. van Eck NJ, Waltman L. VOSviewer [Internet]. Leiden (NL): Leiden University; 2010 [cited 2017 Dec 8]. Available from: http://www.vosviewer.com

39. Perianes-Rodríguez A, Waltman L, Van Eck NJ. Constructing bibliometric networks: a comparison between full and fractional counting. J Informetr [Internet]. 2016 Nov [cited 2018 Aug 24];10(4):1178-95. Available from: http://dx.doi .org/10.1016/j.joi.2016.10.006

40. Chinchilla-Rodríguez Z, Zacca-González G, Vargas-Quesada B, de Moya-Anegón F. Latin American scientific output in Public Health: combined analysis of bibliometric, socioeconomics and health indicators. Scientometrics [Internet]. 2015 Jan [cited 2018 Aug 24];102(1):609-28. Available from: https://doi.org/10.1007/s11192-014 $-1349-9$

41. Dorta-Contreras AJ. En defensa de nuestra producción científica. Acimed [Internet]. 2006 [cited 2018 Aug 24];14(3). Available from: http://scielo .sld.cu/pdf/aci/v14n3/aci15306.pdf. Spanish.

42. Benet M. Las publicaciones cubanas sobre la atención primaria de salud: una ausencia imperdonable. MEDICC Rev [Internet]. 2013 Apr [cited 2018 Aug 24];15(2). Available from: http:// www.medicc.org/mediccreview/articles/mr_395 es.pdf. Spanish.

43. Silva Ayçaguer LC. Hacia un avance cualitativo en las revistas médicas cubanas. Rev Cubana Inf Cienc Salud [Internet]. 2013 [cited 2018 Aug 24];24(3). Available from: http://www.acimed.sld .cu/index.php/acimed/article/view/501/314. Spanish.

44. Zacca-González G, Chinchilla-Rodríguez Z, Vargas-Quesada B, de Moya-Anegón F. Patrones de comunicación e impacto de la producción científica cubana en salud pública. Rev Cubana Salud Pública [Internet]. 2015 [cited 2018 Aug 24];41(2):200-16. Available from: http://scielo .sld.cu/pdf/rcsp/v41n2/spu03215.pdf. Spanish.

45. Somogyi A, Schubert A. Short communication: correlation between national bibliometric and health indicators: the case of diabetes. Scientometrics [Internet]. 2005 Jan [cited 2018 Aug 24];62(2):285-92. Available from: http://dx.doi .org/10.1007/s11192-005-0021-9

46. Krishnamoorthy G, Ramakrishnan J, Devi S. Bibliometric analysis of literature on diabetes (19952004). Ann Lib Inf Stu [Internet]. 2009 Sep [cited 2018 Aug 24];56(3):150-5. Available from: http:// nopr.niscair.res.in/bitstream/123456789/6569/4/ ALIS\%2056\%283\%29\%20150-155.pdf

47. Caglar C, Demir E, Kucukler FK, Durmus M. A bibliometric analysis of academic publication on diabetic retinopathy disease trends during 1980-2014; a global and medical view. Int J Ophthalmol [Internet]. 2016 Nov 18 [cited 2018 Aug 24];9(11):1663-8. Available from: http://dx.doi/ org/10.18240/ijo.2016.11.21

48. Zacca-González G, Vargas-Quesada B Chinchilla-Rodríguez Z, de Moya-Anegón F. Producción científica cubana en medicina y salud pública: Scopus 2003-2011. TransInformação [Internet]. 2014 Sep-Dec [cited 2018 Aug 24];26(3):281-93. Available from: https://seer.sis.puc-campinas.edu.br/seer/index .php/transinfo/article/view/2632. Spanish.

49. Wagner CS, Leydesdorff L. Network structure, self-organization, and the growth of international collaboration in science. Res Policy [Internet]. 2005 Dec [cited 2018 Aug 24];34(10):1608-18. Available from: https://doi.org/10.1016/j.respol .2005.08.002

50. Huamaní C, González G, Curioso WH, Pacheco-Romero J. Redes de colaboración y producción científica sudamericana en medicina clínica, ISI Current Contents 2000-2009. Rev Med Chile [Internet]. 2012 Apr [cited 2018 Aug 24];140(4):466-75. Available from: http://dx.do .org/10.4067/S0034-98872012000400007. Spanish.

51. Aleixandre Benavent R, González de Dios J, Alonso Arroyo A, Bolaños Pizarro M, Castelló Cogollos L, González Alcaide G, et al. Coautoría y redes de colaboración científica de la pediatría española (2006-2010). An Pediatr (Barc) [Internet]. 2013 Jun [cited 2018 Aug 24];78(6):410. e1-410.e11. Available from: http://dx.do .org/10.1016/j.anpedi.2013.01.002. Spanish.

52. Lancho-Barrantes BS, Guerrero-Bote VP, de Moya-Anegón F. Citation increments between collaborating countries. Scientometrics [Internet] 2013 Mar [cited 2018 Aug 24];94(3):817-31. Available from: https://doi.org/10.1007/s11192 -012-0797-3

53. Lancho-Barrantes BS, Guerrero-Bote VP, Chinchilla-Rodríguez Z, de Moya-Anegón F. Citation flows in the zones of influence of scientific collaborations. JASIST [Internet]. 2012 Mar [cited 2018 Aug 24];63(3):481-9. Available from: https://doi .org/10.1002/asi.21682

54. Narin F, Stevens K, Whitlow ES. Scientific co-operation in Europe and the citation of multinationally authored papers. Scientometrics [Internet] 1991 Jul [cited 2018 Aug 24];21(3):313-23. Available from: http://akademiai.com/doi/abs/ 10.1007/BF02093973

55. Ministry of External Affairs (CU). Necessity of ending the economic, commercial and financial blockade imposed by the United States of America against Cuba. Internet. Havana: Ministry of External Affairs (CU); 2016 [cited 2018 Dec 17]. Available from: http://misiones.minrex .gob.cu/en/articulo/cubas-report-2018-resolu tion-724-united-nations-general-assembly-enti tled-necessity-ending

56. Hernández K, Cárdenas-de-Baños L, FundoraMirabal JA, Dorta-Contreras AJ. Científicos cubanos de la biomedicina más productivos 
en el período 1996-2011 según Medline. Rev Cubana Inf Cienc Salud [Internet]. 2012 [cited 2018 Oct 1];23(4):362-79. Available from: http:// www.acimed.sld.cu/index.php/acimed/article/ view/295. Spanish.

57. Dorta-Contreras AJ, Fundora-Mirabal JA. Redes de colaboración entre España y Latinoamérica sobre esclerosis múltiple. Rev Neurol [Internet]. 2014 Feb [cited 2018 Oct 1];58(3):144. Available from: https://www.researchgate.net/profile/ Alberto Dorta-Contreras/publication/259 957042_Networks_of_collaboration_between Spain_and_Latin_America_on_sclerosis_mul tiple/links/551ad5940cf2bb7540785ba5.pdf. Spanish.

58. Dorta-Contreras AJ, Corrales-Reyes IE, FornarisCedeño Y. Producción científica y colaboración internacional cubana en educación médica. Educ Med [Internet]. 2018 Apr 9 [cited 2018 Oct 1]. Available from: http://dx.doi.org/10.1016/j.edu med.2017.12.005. Spanish

\section{THE AUTHORS}

Ibraín E. Corrales-Reyes (Corresponding author: iecorralesr@infomed.sld.cu), dentist. First- year resident in maxillofacial surgery, Medical University of Granma, Carlos Manuel de Céspedes General University Hospital, Bayamo, Cuba.

Yasmany Fornaris-Cedeño, sixth-year medical student, Medical University of Havana, Comandante Manual Fajardo Medical Faculty; intern, Cuban Neurology and Neurosurgery Institute, Havana, Cuba.

Alberto J. Dorta-Contreras, biochemist with a master's degree in social sciences and doctorate in health sciences. Full professor and senior researcher, Medical University of Havana, Dr Miguel Enríquez Medical Faculty; Central Cerebrospinal Fluid Laboratory, Havana, Cuba.

Christian R. Mejia, physician with master's degrees in epidemiologic research and occupational health and a doctorate in medical sciences, Continental University, Perú.
Josmel Pacheco-Mendoza, veterinarian with a master's degree in information and knowledge management, Bibliometric Research Unit, San Ignacio de Loyola University, Lima, Perú.

Ricardo Arencibia-Jorge, computer scientist with a doctorate in information sciences. Associate researcher, Information Technology, BioCubaFarma, Havana, Cuba.
Submitted: December 8, 2017

Approved for publication: December 15, 2018 Disclosures: None

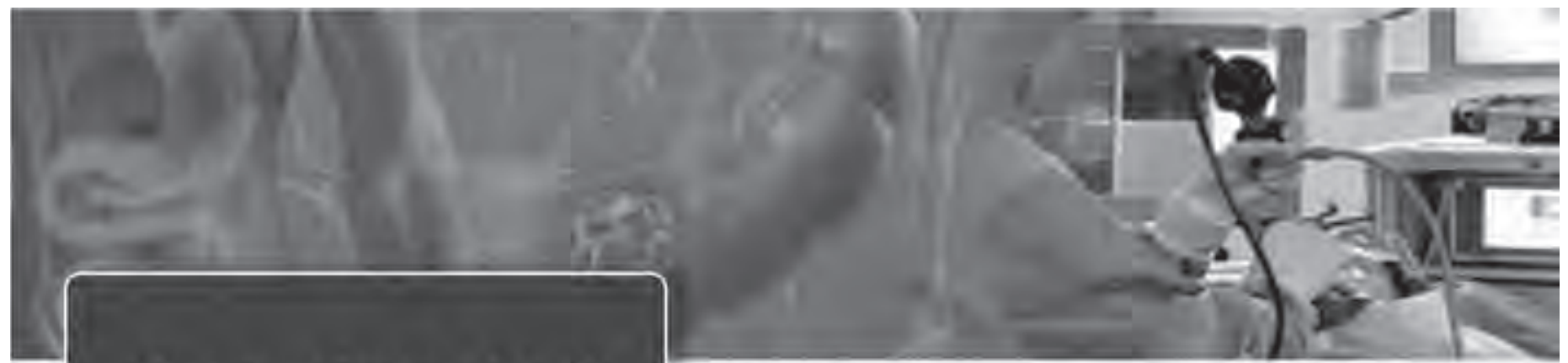

\section{GastroCuba 2019} 7 th Congress of the Cuban Society of Gastroenterology

\author{
Havana's International \\ Convention Center
}

October $21-25,2019$
Main topics:

- Digestive tract cancer

- Inflammatory intestinal diseases

- Liver diseases

- Pediatric gastroenterology

- Diagnostic and therapeutic endoscopy

- Gastroenterologic emergencies

- Nursing in gastroenterology

- Digestive endoscopy - quality of teaching and practice

Languages: Spanish, English

Information: www.gastrocuba2019.com 